\title{
7: 26993083-26983451
}

National Cancer Institute

\section{Source}

National Cancer Institute. 7: 26993083-26983451. NCI Thesaurus. Code C42483.

Physical location of HOXA10_Gene 